\title{
$\mathbf{X}$ 線 管 の 加 熱 特 性について
}

\section{About a Heatercharacter of Filament}

\section{久保田芳男* 吉野純男* 日野昭民米 \\ Yoshio KUBOTA, Sumio YOSHINO, Terumi HINO}

小池利門正杉 猛*

\section{Rimon KOIKE Takeshi HITOSUGI}

\section{緒言}

$\mathrm{X}$ 線管の特性に関し，現在でもまだ充分明らかにさ れていない点が多々あるが，我々はフイラメントの加熱 特性について，フイラメントの温度と加蓺電圧及び加熱 電流との関係を検討した所, 実踰と理諭が極めて良く一 致して一定の関係を有する事を明らかにし得たのでこ」 飞報管する。

\section{実験と理 論}

図 1 は X 線管の加蓺回路を簡単に図式化したもので ある、V は電圧計を A は電流計を示す。愙際に種々

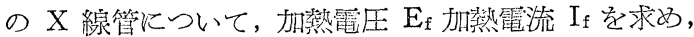
I $\mathrm{I}_{\mathrm{i}}$ を縱軸に， $\mathrm{E}_{\mathrm{f}}$ を横軸にとつて図示したものが図2で ある。

図 2からX 線管によりそれぞれの曲線の傾向は相当

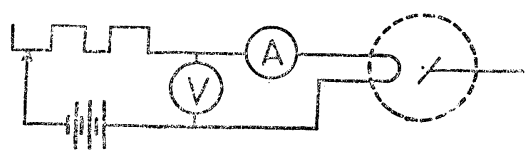

図 1

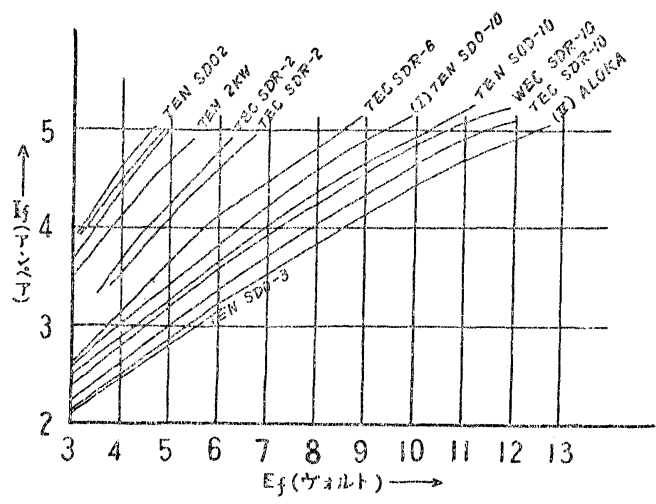

図 2

* 順天堂大学学学部放射線添学教公 1960年8月19日受付
互に異つて居る事が知られた。此の実験に基いて，加熱 特性を理論的飞追究して見た。

先づ，加熱されたフイラメントの熱エネルギーはどの 椂にして失われて行くか即ち篡損の問題を考察した．X 線管内部は高度の真空であるから，対流による熟損は考 えられず，又伝導による熱エネルギーの損失は極めて僅 であり，その大分部は輻射化より失われるものと考兄ら れる．因に，伝導により熱損を検討すべく行つた実験の 結果を図了に示す。

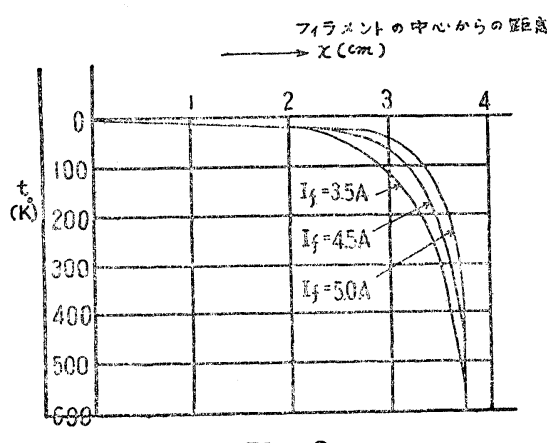

図 3

図の横軸上にフイラメントの中心からの距離を取り， 縱軸の $\mathrm{O}$ の部にフイラメントの最高温度を取つて, そ の下に温度の低下を取つた。図3から見られる様に，フ イラメントの温度の分布状態は大体同一であり，耐端の アンカーに運ばれる熱量は極めて少く，両端より蓺放射 は甚だ僅であつて，平等に加熱されて居る部分だけを問 題にすれびよい事が知られた。以上か，輻射以外の甚 だ㑤なエェネルギーの損失は省略し得るとして理馀をた て〉見た。即ち，フイラメントの面穔を $\mathrm{F}, \mathrm{t}^{\circ} \mathrm{k}$ に於け るタングステンの放熟系数を $\mathrm{At}$, 絶刘温度を $\mathrm{T} \circ \mathrm{k}$ とす ると, Stefon-Boltzmann の泣則 3) 4) 飞従つて

蓺損 $=\mathrm{FAtT}^{4}$

が成り埙つ。

偷 (2) タングステンの放熱系数は，絶刘黑体のそれ の様に一定のbのでなく, 表 1 亿示与様に温度の極数と して変化するものである。 


\section{表 1}

$T \circ K \mid \begin{array}{llllllll}1200 & 1400 & 1600 & 1800 & 2000 & 2200 & 2400 & 2600\end{array}$

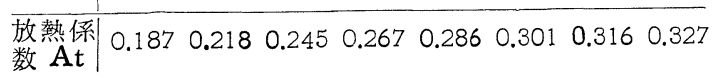
よつて，この関係を実験式を以つて示せば

$$
\mathrm{At}=\mathrm{A}_{0} \mathrm{~T}^{0.8}
$$

こっにAo は常温に於ける放熱柔数とする.

以上の関係を，(1) 式に代入すれば

$$
\text { 熱損 }=\mathrm{FA}_{0} \mathrm{~T}^{4.8}
$$

を得る. 次に入力は $I_{f}, E_{f}$ の積であるが, $\mathrm{t}^{\circ} \mathrm{k}$ に於け る,フイラメントの抵抗を Rt とすると

$$
\text { 入力 }=\mathrm{RtI}_{\mathrm{f}} 2
$$

を得る。

(1) タングステンの $2000^{\circ} \mathrm{K}$ 乃至 $3000^{\circ} \mathrm{K}$ に於る固 有抵抗は表 2 の通りであり,一定值ではない5)。

\begin{tabular}{l|lll} 
& \multicolumn{4}{c}{ 表 } & $\mathbf{2}$ & & \\
絶対温度 $\mathrm{T}^{\circ} \mathrm{K}$ & $2000^{\circ} \mathrm{K}$ & $2500^{\circ} \mathrm{K}$ & $3000 \circ \mathrm{K}$ \\
\hline 固有抵抗 $\mathrm{Rt} \mu \Omega_{\mathrm{cm}}$ & 50.10 & 77.25 & 95.2
\end{tabular}

これ等の数值から, 温度 $\mathrm{T}$ に対応する固有抵抗は, 温度 T の 1.2 乗にほメ゙比例することがわかる。依つて この範囲に於ては

$$
R t=R_{0} T^{1.2}
$$

が成り立つから，これを（4）式に代入して

$$
\text { 入力 }=\mathrm{R}_{0} \mathrm{~T}^{1.2} \mathrm{I}_{\mathrm{f}}
$$

を得る. 入力と熱損は釣り合つているため，(3) 式と (6) 式は等しい. 即ち

$$
\mathrm{FA}_{0} \mathrm{~T}^{4.8}=\mathrm{R}_{0} \mathrm{~T}^{1.2} \mathrm{I}_{\mathrm{f}}{ }^{2}
$$

となる。この式より

$$
\mathrm{T}^{\mathbf{3 . 6}}=\left(\frac{\mathrm{R}_{0}}{\mathrm{FA}_{0}}\right) \mathrm{I}_{\mathrm{f}} 2 .
$$

が導かれる，次で加熱電圧の関係を導入し，オームの法 則より

$$
I_{f} R_{f}=E_{f}
$$

を得る・（8）式に（5）式を代入すると

$$
I_{\mathrm{f}} R_{0} T^{1 \cdot 2}=E_{f}
$$

が得られる。これから $\mathrm{T}$ を出すと

$$
\mathrm{T}=\left[\frac{E_{f}}{I_{f}}\left(\frac{1}{R_{0}}\right)\right]^{\frac{1}{1.2}}
$$

となる・これを（7）式代入すると

$$
\begin{aligned}
& {\left[\frac{E_{f}}{I_{f}}\left(\frac{1}{R_{0}}\right)\right]^{3}=\left(\frac{R_{0}}{F_{0}}\right) I_{f} 2} \\
& \frac{E_{f}}{I_{f}}\left(\frac{1}{R_{0}}\right)^{3}=\left(\frac{R_{0}}{F A_{0}}\right) I_{f} 2
\end{aligned}
$$

$$
\mathrm{E}_{\mathrm{f}}^{3}=\frac{\mathrm{R}_{0}^{4}}{\mathrm{FA}_{0}} \mathrm{I}_{\mathrm{f}} 5
$$

故に, $\mathrm{E}_{\mathrm{f}}=\left(\frac{\mathrm{R}_{0}^{4}}{\mathrm{FA}_{0}}\right)^{\frac{1}{3}} \mathrm{I}_{\mathrm{f}}-\frac{5}{3}$

佮, カッコ内の $\mathrm{F}, \mathrm{A}_{0}, \mathrm{R}_{0}$, は何れも常数であるか ら，Kと持きかえると，

$$
\mathrm{E}_{\mathrm{f}}=(\mathrm{K}) \mathrm{I}_{\mathrm{f}} \mathbf{1 . 6}
$$

となる. 従つて $\mathrm{E}_{\mathrm{f}}$ と $\mathrm{I}_{\mathrm{f}}$ の関係は両方を対数目盛でと つて図示すれば直線となり，且，其の勾配は1.6にな る.図 2 に示した実験結果を両対数目盛にとつて, 実験 結果を図示すると, 図4 亿示す様に勾配が概ね 1.6 の直 線となり，此処儿理論值と笑験值が極めてよく一致して いる事が見られる。

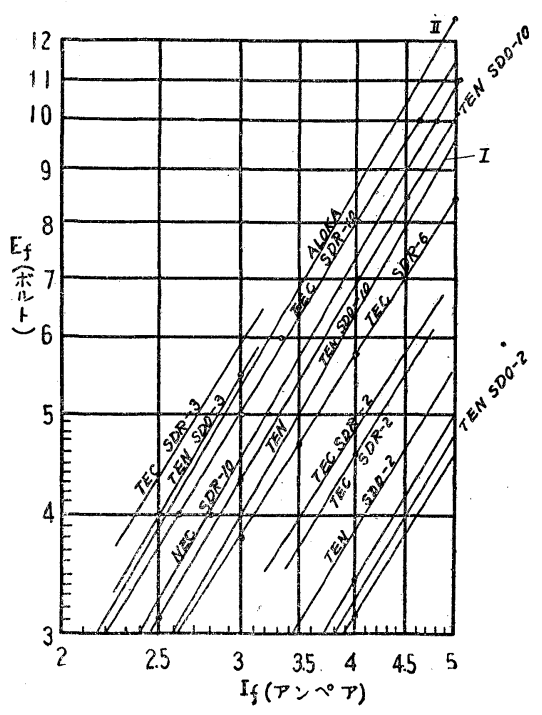

図 4

\section{凟料の吟味}

次で，更に実除資料の正確を斯するために資料の吟味 を行つた。

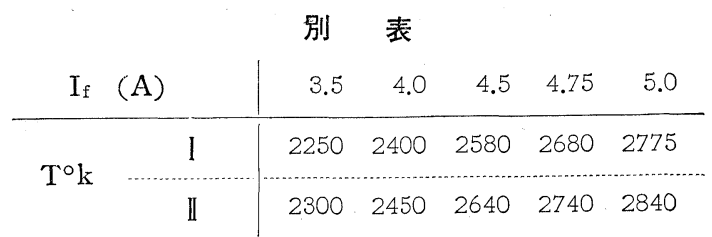

図4の内でI，II の番号を附した X 線管のフイラメ ント温度及びフイラメント加熱電流を測定した結果は別 表に示す通りである。

図4より，その加熱電流に対する加熱電压を求め， 


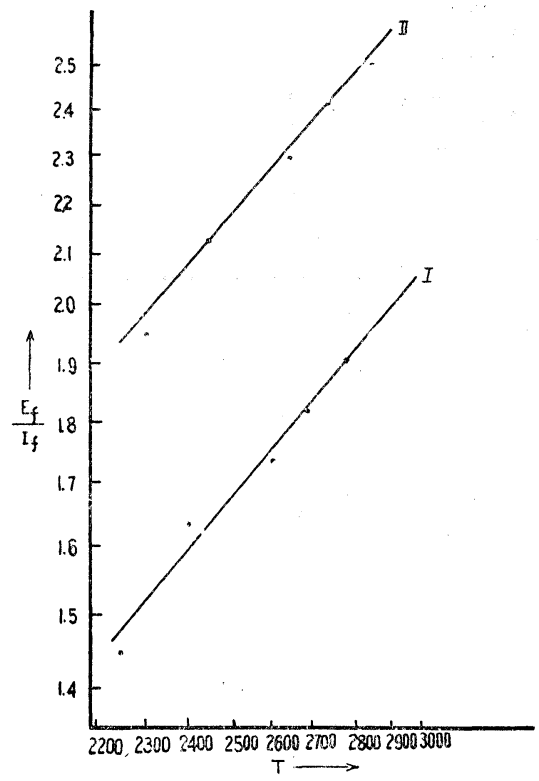

図 5

縦軸に $\frac{E_{\mathrm{f}}}{I_{\mathrm{f}}}$ を, 横軸に $\mathrm{T}$ をとり，両方を対数目盛で図

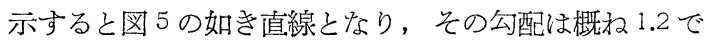
$I_{f} R_{0} T^{1.2}=E_{\mathrm{f}}$ なる（9）式に一致し資料の正確なる事を 確認した. 更に同一の実験から熱損 $=\mathrm{FA}_{0} \mathrm{~T}^{4.8}$ なる（3） 式の吟味:を行つた. (3) 式の熱損は入力即ち $I_{f}$ と $E_{f}$ の䅡と釣合うため， $\mathrm{I}_{\mathrm{f}} \mathrm{E}_{\mathrm{f}}=\mathrm{FA}_{0} \mathrm{~T}^{4.8}$ なる式を導き， $\mathrm{F}$ 及び $\mathrm{A}_{0}$ は定数なるため, 縦軸活 $\mathrm{E}_{\mathrm{f}}$ を横軸に $\mathrm{T}$ を 夫々対数目盛でとると図6亿示す様な直線となり, 勾配 は概ね 4.8 で資料を吟味し得た。

\section{結語}

我々は, $\mathrm{X}$ 線のフイラメントの温度と, フイラメン トの加熱電圧及び加熱電流との関係を垁験的及び理論的 に追究した所，その関係を明らかにする事が出来た。

フイラメントの熱電子放射は, フイラメントの温度に

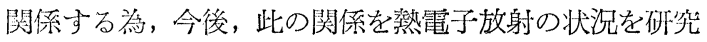
する際の足がかりになり得るものと思う。

本諭文の要旨は第69回順天堂医学会 例会に報告 した。

稿を終るにあたり，御指導，御校蛽安戴いた土屋 教授，及び水木先生に心より感謝を致します，又御

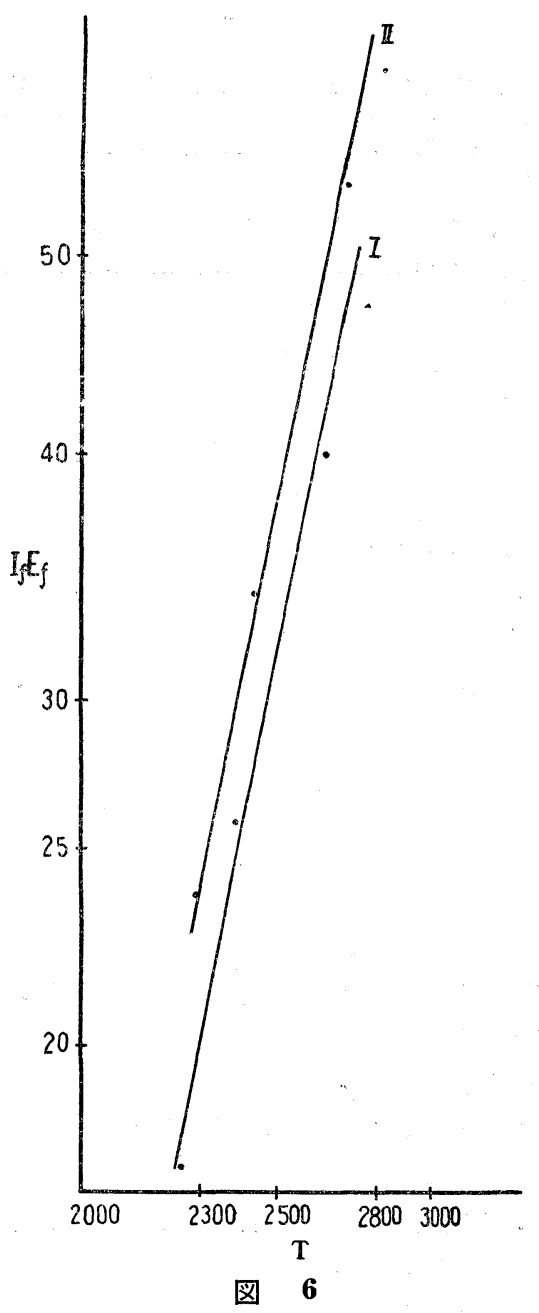

協力頂いた教室員各位に謝意を裴します。

文献

1) Forsyche, \& Worthing,: Astro Physicol, J. 61, 146, (1925)

2) W. Coblentz,: Internal Citcal Table 5, p. 243.

3) 本多光太婂：物理学:本渝, 341 .

4) Schmidt, E.: Wärmestrahlung techuischer Oberflächen bei Gewöhnlicher Temperatur Beihefte Ges Ing, Reihe I, Heft 20 R Odenburg (1927)

5) 汇藤秀崔：放射線䀢学，4，(1954) 


\section{Summary}

Studying the relation between the temperature of R-ray tube filament and the heatervoltage or the heatercurrent experimentally and theoretically.

We find the fact that emission of election from filament depend upon the temperature of filament, perhaps we shall be able to make use of this relationship when we study the appearance of emission hereafter.

Department of Radiology, Juntendo University, School of Medicine. 